\title{
Gastric Cancer Pathologic TNM Finding v8
}

National Cancer Institute

\section{Source}

National Cancer Institute. Gastric Cancer Pathologic TNM Finding v8. NCI Thesaurus.

Code C133601.

A pathologic finding about one or more characteristics of gastric cancer, following the rules of the TNM AJCC v8 classification system. 